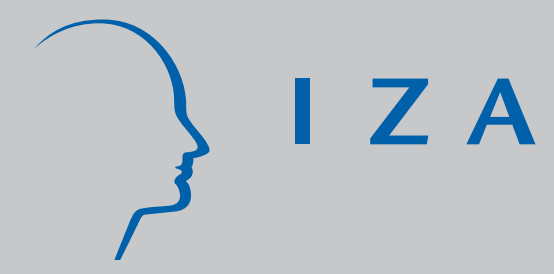

IZADP No. 2595

A Persistence Model of the National Minimum Wage

Melanie K. J ones

Richard J. J ones

Philip D. Murphy

Peter J . Sloane

February 2007 


\title{
A Persistence Model of the National Minimum Wage
}

\author{
Melanie K. Jones \\ WELMERC, University of Wales at Swansea \\ Richard J. Jones \\ WELMERC, University of Wales at Swansea \\ Philip D. Murphy \\ WELMERC, University of Wales at Swansea \\ Peter J. Sloane \\ WELMERC, University of Wales at Swansea \\ and IZA
}
Discussion Paper No. 2595
February 2007

IZA

P.O. Box 7240

53072 Bonn

Germany

Phone: +49-228-3894-0

Fax: +49-228-3894-180

E-mail: iza@iza.org

\begin{abstract}
Any opinions expressed here are those of the author(s) and not those of the institute. Research disseminated by IZA may include views on policy, but the institute itself takes no institutional policy positions.

The Institute for the Study of Labor (IZA) in Bonn is a local and virtual international research center and a place of communication between science, politics and business. IZA is an independent nonprofit company supported by Deutsche Post World Net. The center is associated with the University of Bonn and offers a stimulating research environment through its research networks, research support, and visitors and doctoral programs. IZA engages in (i) original and internationally competitive research in all fields of labor economics, (ii) development of policy concepts, and (iii) dissemination of research results and concepts to the interested public.
\end{abstract}

IZA Discussion Papers often represent preliminary work and are circulated to encourage discussion. Citation of such a paper should account for its provisional character. A revised version may be available directly from the author. 
IZA Discussion Paper No. 2595

February 2007

\section{ABSTRACT}

\section{A Persistence Model of the National Minimum Wage}

This paper utilises the panel element of the BHPS (waves 9 to 14) to examine the dynamics of the National Minimum Wage (NMW) introduced to Britain in 1999. Specifically a persistence measure based on a random effects probit model for those affected by the NMW is constructed. The conditional probabilities imply some degree of state dependence, but there is also a considerable amount of turnover from one year to the next among those affected by the NMW.

JEL Classification: J0, J3, K31

Keywords: National Minimum Wage, state dependence, wage mobility

Corresponding author:

Peter J. Sloane

WELMERC, School of Business and Economics

Swansea University, Richard Price Building

Singleton Park

Swansea SA2 8PP

United Kingdom

E-mail: p.j.sloane@swansea.ac.uk 


\section{INTRODUCTION}

This research into the dynamics of the National Minimum Wage (NMW) ${ }^{1}$ investigates the persistence of work paid at or around the minimum, the characteristics of those that remain in low paid work, and the proportion of employees affected by the NMW. Obviously, if minimum wage jobs are mainly entry-level jobs which only have shortterm effects on lifetime earnings this is a much less serious policy issue than if they are mainly dead-end jobs, providing workers with few opportunities for positive wage growth $^{2}$.

If there is persistence in minimum wage employment it is important to know the cause. Such persistence could be the consequence of particular personal characteristics of those in this state or it could be due to a causal link between previous labour market experience and minimum wage employment. That is, it is important to disentangle the effects of unobserved individual heterogeneity and true state dependence, controlling for observable characteristics. True state dependence (sometimes referred to as scarring) occurs when there is an causal relationship between previous and current labour market experience, so that an individual experiencing minimum wage unemployment now will behave differently in the future than someone who is not in minimum wage employment. Of particular significance is whether previous non employment makes an individual more likely to experience minimum wage employment when entry to the labour market occurs. Firms may be more likely to offer employment at minimum wages to such individuals because they

\footnotetext{
${ }^{1}$ We are grateful to the Low Pay Commission for financing this research and to Stephen Jenkins for helpful comments. The conclusions drawn are, however, those of the authors and do not necessarily reflect the views of the Commission.

${ }^{2} \mathrm{~A}$ further related question is whether the same individuals experience minimum wage employment year after year or whether the incidence of such employment affects different individuals from one year to the next. However, our methodology does not enable us to cast much light on this, as we do not include new entrants into minimum wage employment other than in the initial year of the panel.
} 
are less likely to have appropriate work experience or because non-employment is used as a signal to employers that such individuals are likely to be low productivity workers. Or perhaps workers with periods of non-employment lower their reservation wages in order to secure any job, thus making minimum wage employment more likely.

As Arulampalam et al (2000) note, is can be difficult to distinguish between unobserved heterogeneity and state dependence because of the initial conditions problem. However, we have the advantage of starting our analysis in 1999 when the National Minimum Wage was first introduced in Britain. Stewart (2005) implies that initial conditions can be taken as exogenous if the start of the process coincides with the start of the observations period for each individual.

In the context of this study not only the introduction of the minimum wage in April 1999 at $£ 3.60$ an hour for adults and $£ 3.00$ per hour for youths (for 18 to 21 year olds) is pertinent, but also adjustments made to these rates thereafter. As illustrated in Figure 1 further increases were awarded in the case of the adult rate in October 2000 (£3.70), October 2001 (£4.10), October 2002, (£4.20), October 2003 (£4.50), October 2004, (£4.85), and October 2005 (£5.05). A further increase to $£ 5.35$ occurred in October 2006. There were corresponding increases for young persons, but the percentage increases were not identical for each group. ${ }^{3}$ When we use panel data there will be a change in the individuals who are directly affected by the NMW each time it is increased and as the percentage increase is not constant the extent to which the NMW bites will vary. There are a number of ways of measuring this (see Lemos,

\footnotetext{
${ }^{3}$ As shown in Figure 1 a NMW is also to be introduced for 16-17 year olds, previously exempt, from October 2004, initially set at £3.00 per hour.
} 
2004). One possible measure is the real minimum wage. Another is the log Kaitz index (Kaitz, 1970), which is defined as the ratio of the minimum wage to the average wage adjusted for coverage. The 'fraction affected' will not be the same as the 'fraction at', as workers traditionally above the minimum, but now captured by it, may bargain to have their wages raised above the minimum. In this paper we measure bite as the ratio of the adult minimum wage to median adult hourly pay and the employment rate as number employed as a ratio of all individuals of working age.

In this paper we use data from the British Household Panel Survey over the period 1999 to 2004 (waves 9 to 14) to construct a persistence measure based on probit analysis with random effects for those affected by the minimum wage.

\section{PREVIOUS WORK}

As far as we are aware direct evidence on the dynamics of minimum wages is limited to the USA. One study (Smith and Vavrichek, 1992) reported that over $60 \%$ of workers in receipt of the minimum wage in 1984 were earning more than the minimum one year later. More recently Evan and McPherson (2003) compared minimum wage workers with a comparison group earning above the minimum, using panel data drawn from the Current Population Survey over the period 1979-1999. Their evidence suggests that minimum wage jobs tend to be entry-level jobs and that they are also of short duration for a large majority of workers. Factors most likely to assist wage growth (or movement above the minimum) are education and training and changes of industry and occupation. This is after a correction for sample selection, which is required because earnings are only observed for those who remain in employment. 
As far as Britain is concerned work on the dynamics of low pay has some relevance (see, for example, Asplund, Sloane and Theodossiou, editors, 1988, Stewart and Swaffield, 1999, Sloane and Theodossiou, 2000, Bradley et al., $2003^{4}$ and Stewart, 2005). One may summarise this literature as suggesting that the longer workers remain in low paid jobs, the more difficult it becomes to escape from them (low pay persistence). This scarring effect of low pay can result as a consequence of the characteristics of individuals themselves (heterogeneity) or the carry over of the experience of low pay from one period to the next (structural dependence). The evidence suggests that the latter is much more important than the former. As well as having a relatively high probability of remaining low paid, this group is also more likely to move out of employment (the low-pay, no-pay cycle). There is little evidence for this group that low paid jobs act as stepping stones to higher paid jobs, which might offset the above disadvantage. The strongest evidence for this is found in Stewart (2005) who presents results consistent with the hypothesis that low wage jobs do not augment human capital significantly more than unemployment. Therefore, it does appear that experience of low pay causes some workers to be trapped there. Low pay appears also to be associated with long-run earnings inequality in the sense that as the earnings distribution widens the number of workers classified as low paid increases. To some extent, institutional arrangements, such as union membership and collective bargaining coverage, serve to moderate these effects by compressing the lower tail of the earnings distribution. Yet, we should be cautious

\footnotetext{
${ }^{4}$ Bradley et al. adopt a somewhat different approach by distinguishing between five labour market states - high skilled employment, intermediate skilled employment, low skilled employment, unemployment and out of the labour force. Using the first seven waves of the BHPS they identify two particular groups. One of them in the high skilled sector is more likely to remain in or move between jobs in that sector. The other (the socially excluded) tends to move between low skilled employment, unemployment and inactivity. This is taken as evidence of sectoral persistence.
} 
in equating low pay with minimum pay. First, minimum wage workers are located at a lower moment in the earnings distribution than low-paid workers, who are conventionally defined as earning less than two-thirds of the male median wage and who are not subject to statutory wage provisions. Second, there are statistical problems in using the standard data sets to identify those subject to the minimum wage that are much more severe than is the case with respect to low-paid workers.

A number of studies have focused on the incidence of minimum wages for particular groups in the labour market. The LPC itself estimated at the time of the introduction of the NMW in 1999 that it would impact on 3 per cent of male full-timers, 26 per cent of male part-timers, 5 per cent of female full-timers and 22 per cent of female part-timers, implying that three-quarters of the recipients would be female. Despite this Dex, Sutherland and Joshi (2000) estimated the effect on the gender pay gap to be small. This result was confirmed by Robinson (2002) who suggests, on the basis of a simulation using the 1999 Labour Force Survey, that it would require a NMW as high as $£ 5$ per hour at that time to reduce the gender gap by 3 percentage points. As for regional differences Stewart (2002) found that, although the minimum wage had differential wage distribution effects across 140 areas of the country, employment growth after its introduction was not significantly lower in areas of the country with high proportions of workers paid below the minimum before it was introduced than in areas with low proportions of such workers. One study (Burchardt and McKnight, 2003) has examined the effect of the NMW on the disabled, finding that 5 per cent of the non-disabled and 9 per cent of the disabled were earning less than the adult minimum wage in the post-NMW period, which they attribute to non-compliance or measurement error in the LFS. They also find that disabled employees earning less 
than the minimum prior to its introduction did not enjoy the same improvement as the non-disabled. Finally, Dickens and Manning (2002) have estimated the impact of the NMW on wage inequality, finding that it does have a detectable effect on the wage distribution, though it has had virtually no effect on the pay of workers who are not directly effected. While these studies are a useful background to our own study they do not examine persistence effects for employers or different sub-groups of employees affected by the NMW. 


\section{FIGURE 1}

CHANGES IN THE NATIONAL MINIMUM WAGE

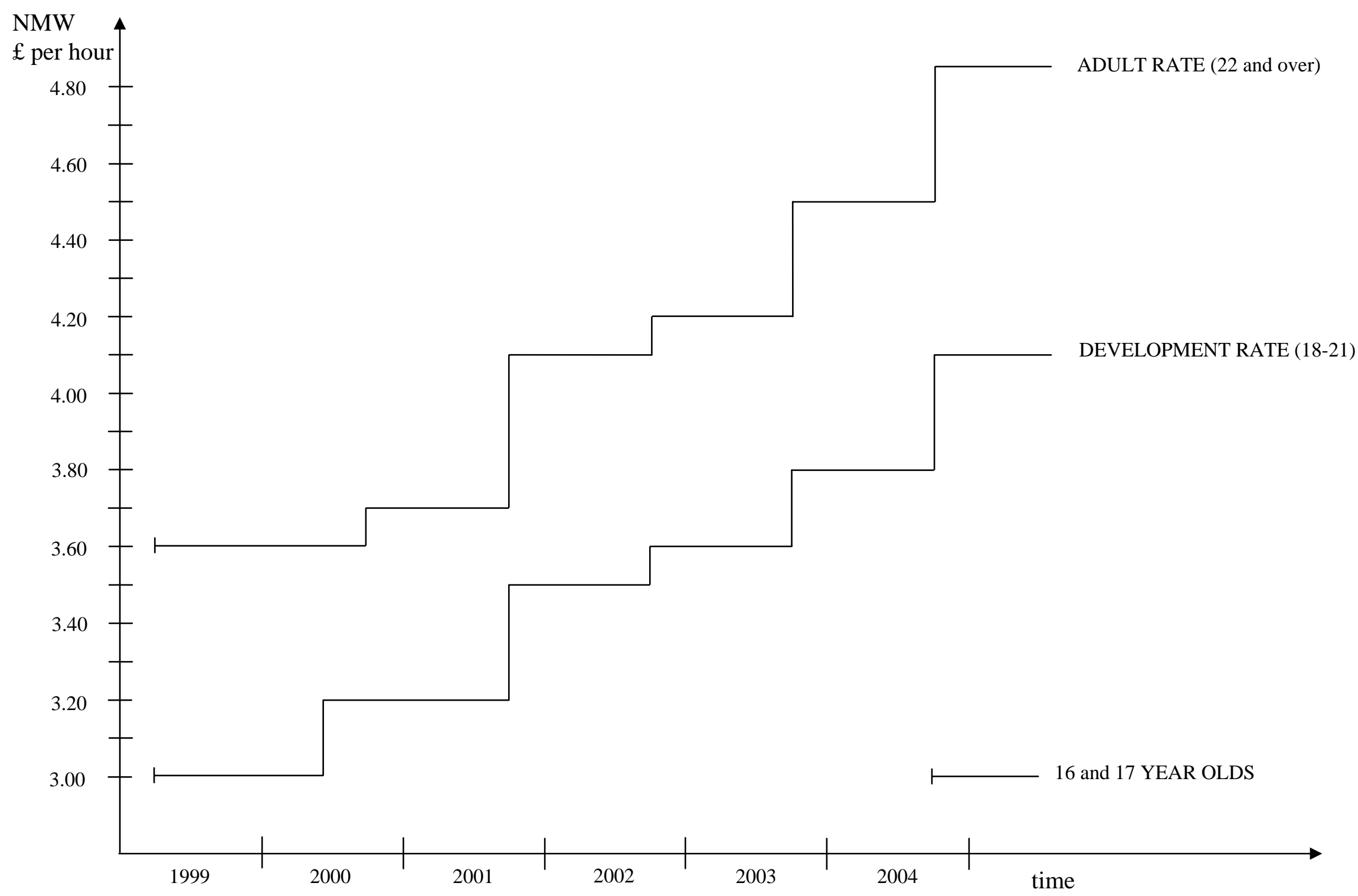




\section{RESEARCH METHODS AND SAMPLING}

\section{(i) Data and Research Methodology}

The BHPS, is an annual survey of a nationally representative set of households in Great Britain and has the advantage of being a full panel, which enables users both to track individuals over a longer period of time and to control for unobservables that might otherwise affect labour market outcomes. The BHPS also covers the complete earnings distribution with careful checks on individual pay. Further, wave 9 included additional questions in order to evaluate the impact of the NMW (see Stewart and Swaffield, $2002)^{5}$

The data are from waves nine to fourteen ${ }^{6}$ and the sample consists of an unbalanced panel of employees of working age (i.e. males aged 18-65 and females aged 18-60) in Great Britain who are :

(i) in paid employment in wave 9

(ii) who give full interviews

(iii) and who are not students, individuals on government training schemes or members of the armed forces.

No new individuals enter the sample ${ }^{7}$.

We use derived hourly rate of pay (rather than basic hourly earnings) in order to maximise sample size. This is usual gross weekly earnings divided by total paid hours

\footnotetext{
${ }^{5}$ For the first time data were collected on basic hourly wage rates for hourly paid workers and overtime premium payments for all employees, thus allowing an implied basic rate for all non-hourly paid workers to be constructed which has been shown to better identify pay spikes at the NMW that are otherwise obscured when average hourly wage data are used.

${ }^{6}$ A full description of BHPS is given in Taylor, Brice and Prentice-Lane (2001).

${ }^{7}$ We exclude the boost for Scotland and Wales and data for Northern Ireland.
} 
(basic plus paid overtime) worked in a normal week. ${ }^{8}$ This does not identify the spike in earnings as well as the basic pay variable, but it does appear to behave in a similar manner over time ${ }^{9}$.

As Cappellari and Jenkins (2004) point out the usefulness of multiple regression models of low pay transition probabilities are contingent on the ability to deal with issues such as non-random attrition, non response on key economic variables and nonrandom selection into low pay in the base year (the initial conditions problem). Using the BHPS waves 1 to 10 they find that the problem of panel attrition can be ignored and we do not deal with this problem here. They also conclude that relatively simple models provide estimates of covariate marginal effects that differ little from those provided from more complicated models. The procedure we adopt to deal with the initial conditions problem assumes the model is the same for those experiencing a previous episode of NMW employment as it is for those who enter NMW employment from non employment.

An important policy issue is whether the same men and women are paid at or below the NMW year-on-year, or whether the stock of individuals affected by the NMW is characterised by high inflow and outflow rates. Economists refer to movements into and out of a stock as 'churning', and if individuals affected by the NMW typically experience high turnover rates their stay in low paid work can be quite short. Alternatively, if turnover rates for some groups of workers are low, and their chance of

\footnotetext{
${ }^{8}$ This is the same hourly rate as used by Stewart and Swaffield (2002).

${ }^{9}$ Focusing on adults in wave 9 of the BHPS and using basic hourly earnings 1.5 per cent of the sample are paid less than the minimum and 8.1 per cent precisely the minimum of $£ 3.60$ per hour. Using derived average hourly earnings the BHPS provides a figure of 5.6 per cent below the minimum and 0.3 per cent at the minimum
} 
being affected by the NMW is influenced by previous episodes of pay at or below the NMW, then their chance of exiting low pay may be state dependent.

Although the BHPS cannot be used directly to analyse NMW durations, the panel nature of the data can be exploited to construct a persistence measure for those affected by the NMW. Therefore, we use the BHPS to see how an individual's current propensity of being at or below the NMW is affected by previous experiences of being paid at or below the NMW.

\section{(ii) Model Specification}

We start with the simplest dynamic model of employment at or below the NMW, namely:

$\mathrm{y}_{1 \mathrm{it}}=1\left(\mathrm{x}_{\mathrm{it}} \beta+\gamma_{1} \mathrm{y}_{2 \mathrm{it}-1}+\gamma_{2} \mathrm{y}_{1 \mathrm{it}-1}+\varepsilon_{\mathrm{i}}+\mathrm{v}_{\mathrm{it}}>0\right)$

where $\mathrm{y}_{1 \mathrm{it}}$ takes the value 1 if the ith individual is employed at or below the NMW and 0 if employed above the NMW at time t; $\mathrm{y}_{2 \mathrm{it}-1}$ takes the value 1 if the ith individual is not employed at time $\mathrm{t}-1$ and zero otherwise; $\mathrm{x}_{\mathrm{it}}$ is a vector of explanatory variables; $\varepsilon_{\mathrm{i}}$ is an individual specific measure of unobserved heterogeneity; and $v_{\text {it }} \sim \mathrm{N}\left(0, \sigma_{v}\right)$ is a standard disturbance.

Before (1) can be estimated two problems need to be addressed; first, the standard random effects model assumes $\varepsilon_{\mathrm{i}}$ is uncorrelated with $\mathrm{x}_{\mathrm{i}}$; second, the initial conditions problem, which implies that $\varepsilon_{\mathrm{i}}$ and $\mathrm{y}_{1 \mathrm{i} 0}$ are correlated.

If left untreated both problems can lead to inconsistent estimates and badly biased estimates. 
Following Mundlak (1978) and Chamberlain (1984) correlation between $\varepsilon_{\mathrm{i}}$ and observed characteristics in $\mathrm{x}_{\mathrm{it}}$ is allowed by assuming a relationship of the following form:

$\varepsilon_{\mathrm{i}}=\overline{\mathrm{x}}_{\mathrm{i}}^{\prime} \alpha+\alpha_{\mathrm{i}}$

where $\alpha_{\mathrm{i}}$ is a measure of unobserved heterogeneity which is independent of $\mathrm{x}_{\mathrm{it}}$ and $\overline{\mathrm{x}}_{\mathrm{i}}^{\prime}$ are the means of the time varying variables for each individual ${ }^{10}$. The adjusted model can therefore be written as:

$$
\mathrm{y}_{1 \mathrm{it}}=1\left(\mathrm{x}_{\mathrm{it}} \beta+\gamma_{1} \mathrm{y}_{2 \mathrm{it}-1}+\gamma_{2} \mathrm{y}_{1 \mathrm{it}-1}+\overline{\mathrm{x}}_{\mathrm{i}}^{\prime} \alpha+\alpha_{\mathrm{i}}+\mathrm{v}_{\mathrm{it}}>0\right)
$$

To account for the initial conditions problem we use the Conditional Maximum Likelihood estimator suggested by Wooldridge (2005), which models the conditional density of $\mathrm{y}_{1 \mathrm{t}}$ given $\mathrm{x}$ and $\mathrm{y}_{10}{ }^{11}$. The model for $\alpha_{\mathrm{i}}$ is written as:

$$
\alpha_{\mathrm{i}}=\alpha_{0}+\alpha_{1} \mathrm{y}_{10}+\omega_{\mathrm{i}}
$$

where $\omega_{\mathrm{i}} \sim \mathrm{N}\left(0, \sigma_{\alpha}\right)$. Substituting (3) into (1a) gives:

$$
\mathrm{y}_{1 \mathrm{it}}=1\left(\mathrm{x}_{\mathrm{it}} \beta+\gamma_{1} \mathrm{y}_{2 \mathrm{it}-1}+\gamma_{2} \mathrm{y}_{1 \mathrm{it}-1}+\alpha_{0}+\alpha_{1} \mathrm{y}_{10}+\overline{\mathrm{x}}_{\mathrm{i}}^{\prime} \alpha+\omega_{\mathrm{i}}+\mathrm{v}_{\mathrm{it}}>0\right)
$$

Estimates of (1a), and 1(b), and a pooled probit model for comparison purposes, are reported in the main results section.

\footnotetext{
${ }^{10}$ In practice many of the variables included in the model are binary variables and they do not vary much over the estimation period. Consequently the variables included in $\overline{\mathrm{X}}_{\mathrm{i}}^{\prime}$ in the results section are restricted to age; age squared; length of job tenure; the regional employment rate; and regional bite variable.

${ }^{11}$ Even if the process is observed from its inception the assumption of independence between $\alpha_{\mathrm{i}}$ and $\mathrm{y}_{10}$ is still very strong and if violated would still require a correction for initial conditions.
} 


\section{Marginal Effects}

The effect that previous labour market status ( $\mathrm{y}_{1 \mathrm{it}-1}$ or $\left.\mathrm{y}_{2 \mathrm{it}-1}\right)$ has on the probability of employment at or below the NMW is based on two counter-factual probability calculations (Wooldridge, 2005). Specifically, for the model given in 1(b):

$$
\begin{aligned}
& \hat{p}_{0}=N T^{-1} \sum_{i=1}^{N} \sum_{t=1}^{T_{i}} \Phi\left(x_{i t} \hat{\beta}+\hat{\alpha}_{0}+\hat{\alpha}_{1} y_{10}+\bar{x}_{i}^{\prime} \hat{\alpha}\right) \text { and } \\
& \hat{p}_{j}=N T^{-1} \sum_{i=1}^{N} \sum_{t=1}^{T_{i}} \Phi\left(x_{i t} \hat{\beta}+\hat{\gamma}_{j}+\hat{\alpha}_{0}+\hat{\alpha}_{1} y_{10}+\bar{x}_{i}^{\prime} \hat{\alpha}\right)
\end{aligned}
$$

where $\Phi$ is the cumulative normal distribution function, $T_{i}$ is the number of employment episodes observed, $\mathrm{T}$ is the sum of $\mathrm{T}_{\mathrm{i}}$, and hats over parameters indicate maximum likelihood estimates.

Two comparison probabilities are then reported in the tables reported below. First the average partial effect $(\mathrm{APE})=\hat{\mathrm{p}}_{\mathrm{j}}-\hat{\mathrm{p}}_{0}$ and the predicted probability ratios (PPR) $\hat{\mathrm{p}}_{\mathrm{j}} / \hat{\mathrm{p}}_{0}$ and $\hat{\mathrm{p}}_{2} / \hat{\mathrm{p}}_{1}$.

\section{RESULTS}

\section{(i) Some Descriptives}

Means of the variables are presented in Table 1. In general the distributions are as one would expect with 83 per cent of those paid at or below the minimum wage being female. The low paid are also less likely to have qualifications, less likely to be employed in larger establishments, less likely to have promotion possibilities or managerial responsibilities, less likely to be employed full time and less likely to be in a unionised workplace. Among industries construction stands out as having a disproportionate number of its workers paid at or below the minimum wage (32 per cent of all those at or below the NMW in our 
sample). Two-thirds of those at or below the NMW are also concentrated in three occupational groups - personal and protective services, sales and other occupations. There do not appear to be strong regional differences in NMW incidence or in employment rates or regional bite of the NMW.

\section{(ii) The persistence model}

Here we are concerned with the persistence of employment at or below the NMW, and in particular whether being paid at or below the NMW in one period increases the probability of being affected by the NMW in future periods. One way of looking at this issue is to consider the conditional probability of an individual being paid at or below the NMW in year $t$ given that he or she was either paid at or below the NMW or above the NMW in year $t-1$. Based on the data taken from the BHPS these conditional probabilities, along with the unconditional probability of being affected by the NMW, are reported in Table

2. The unconditional probability of being paid at or below the NMW varies between 5.6 per cent and 6.9 per cent and does not exhibit any clear trend. The conditional probabilities lie between 29 per cent and 35 per cent, implying a substantial degree of state dependence, though without controls for individual heterogeneity. That is an individual's chance of being employed at or below the NMW in the current period depends in part on whether they were employed at or below the NMW in the previous period. However, as pointed out by Heckman (1981) and more recently by Stewart (1999), such conditional probabilities do not necessary prove the existence of state dependence of employment at or below the NMW, as they can equally arise as a result of either observed or unobserved heterogeneity, particularly where characteristics that 
exhibit persistence over time are associated with an increased chance of being paid at or below the NMW.

Labour market status transitions for the three categories - not employed, employed at or below the minimum wage and employed above the NMW are provided in Table 3. The large majority of those not employed remain so from one year to the next, but those entering the labour market are six times more likely to end up with wages above the NMW as at or below it. Nearly 15 per cent of those paid at or below the NMW move out of employment, over a third remain in that state and over 50 per cent move into more highly paid employment, so that there is considerable upward mobility even over a period as short as one year. Over 92 per cent of those in higher pay remain in that state with relatively few moving into minimum wage employment or out of the labour market.

In Table 4(a) we provide dynamic probit estimates of employment at or below the NMW. Previous labour market status, whether that indicates either nonemployment at $\mathrm{t}-1$ or paid at or below at $\mathrm{t}-1$, is significant in both models (Pooled Logit and Random Effects Probit, which includes both Mundlak and Wooldridge corrections ${ }^{12}$. The coefficients indicate that those individuals who experience an episode of non-employment or employment at or below the NMW at t-1 are more likely to be in low paid employment at time t. The difference between these estimates is significant, and is reflected in the sizes of

\footnotetext{
${ }^{12}$ As noted above only continuous variables were used for the Mundlak correction. Of these mean age and mean age squared were significant, that the tenure, bite and employment measures were not.
} 
both the predicted probabilities of being paid at or below the NMW $-\hat{p} 1$ and $\hat{p} 2$ - and the predicted relative probabilities.

The significance of a previous episode of minimum wage employment in both specifications strongly supports the existence of persistence, although controlling for unobserved heterogeneity and initial conditions dampens down the magnitude of the response. Thus relative to an individual who is employed at or above the NMW at $\mathrm{t}-1$, an individual in minimum wage employment at $\mathrm{t}-1$ is 13.6 per cent more likely to be in minimum wage employment at time 1 according to the pooled probit model. However, once unobserved heterogeneity and initial conditions are controlled for this probability falls to 4 per cent. The equivalent effect produced by an episode of non-employment at t-1 in each model is 4.0, and 2.6 per cent respectively. For the random effects model these are relatively small but nonetheless significant effects.

The significance of the rho parameter in the Random Effects Model suggests that controlling for unobserved heterogeneity is important as individual heterogeneity accounts for 20 per cent of the total error variance. Controlling for initial conditions also clearly impacts on the reported marginal effects.

A consistent pattern is shown for the effect that other covariates have on likelihood of minimum wage employment. Thus the likelihood of minimum wage employment is higher for females, older workers, individuals in poor health, those working in smaller establishments, those with no managerial or supervisory responsibilities working in jobs with few promotion possibilities, 
individuals working in non-union establishments; and individuals in lower status occupations (measured relative to Professionals). This is in accordance with other studies using different data sets such as the Labour Force Survey (See for instance Jones et al (2004)).

Industry and region effects are not as pronounced as might be expected as only in construction does the coefficient turn out to be significant at conventional levels. No significant effects were found for either the bite or employment variables, although given that these variables are measured at the same level of regional dissaggregation as the regional variables already included in the model it might be overly optimistic to expect the model to be able to identify these separate effects. $^{13}$ For this reason we reran the model excluding the regional bite and employment rate variables (Table 4(b)). This had little effect on the industry dummies but did impact on the regional dummies. Now six regions (East Midlands, North-East, Scotland, Wales, West Midlands and Yorkshire and Humberside) have significantly higher proportions of minimum wage workers relative to the omitted region, London and the South-East.

\section{CONCLUSIONS}

The evidence on low pay dynamics revealed by the analysis of the BHPS supports the persistence model for a minority of workers on or below the NMW, but the effect is relatively small and a substantial majority of workers move rapidly out of minimum wage employment. The results suggest that it is important to correct for unobserved heterogeneity and initial conditions, both of which serve to reduce the size of the

\footnotetext{
${ }^{13}$ Here bite is measured by the ratio of the current NMW to adult basic hourly earnings in each region and the regional employment rate as the ratio of employment to working age population.
} 
persistence coefficients, which still, however, remain significant. These results contrast with results for low paid workers, where it has been found that low wage jobs typically do not lead on to better things and suggest that it is dangerous to infer that different moments of the earnings distribute operate in similar ways. It should be noted that we do not rule out the possibility of a low-pay no-pay cycle as our methodology does not allow us to capture the return of those who leave minimum wage employment for unemployment and later return to minimum wage employment. However those entering employment from unemployment are much more likely to enter higher paid employment than minimum wage employment. 
Table 1: Means of Variables: BHPS 1999-2004

\begin{tabular}{|c|c|c|c|}
\hline & All Employees & $\begin{array}{c}\text { Employees } \\
\text { Paid at or } \\
\text { below the } \\
\text { NMW }\end{array}$ & $\begin{array}{c}\text { Employees Paid } \\
\text { Above the NMW }\end{array}$ \\
\hline Female & 0.52 & 0.83 & 0.50 \\
\hline Age & 39.91 & 40.16 & 39.89 \\
\hline Degree/Higher Qualifications & 0.55 & 0.35 & 0.56 \\
\hline A-Level & 0.12 & 0.15 & 0.12 \\
\hline O-Level & 0.18 & 0.22 & 0.18 \\
\hline Other Qualifications & 0.06 & 0.09 & 0.06 \\
\hline Poor Health & 0.05 & 0.09 & 0.05 \\
\hline Married & 0.62 & 0.61 & 0.62 \\
\hline Widowed/Separated/Divorced & 0.13 & 0.17 & 0.13 \\
\hline Job Tenure & 59.37 & 52.61 & 59.68 \\
\hline Establishment 25-99 & 0.25 & 0.23 & 0.25 \\
\hline Establishment 100-499 & 0.26 & 0.16 & 0.26 \\
\hline Establishment 500+ & 0.19 & 0.04 & 0.20 \\
\hline Managerial Responsibility & 0.25 & 0.09 & 0.26 \\
\hline Supervisory Responsibility & 0.16 & 0.12 & 0.16 \\
\hline Promotion Possibilities & 0.52 & 0.34 & 0.53 \\
\hline Full Time & 0.83 & 0.56 & 0.85 \\
\hline $\begin{array}{l}\text { Union/Staff Association at } \\
\text { Workplace }\end{array}$ & 0.54 & 0.30 & 0.55 \\
\hline $\begin{array}{l}\text { Extraction; Manufacture of Metals, } \\
\text { Mineral Products \& Chemicals }\end{array}$ & 0.09 & 0.03 & 0.09 \\
\hline $\begin{array}{c}\text { Metal Goods, Engineering \& } \\
\text { Vehicles Industries }\end{array}$ & 0.07 & 0.02 & 0.07 \\
\hline Other Manufacturing & 0.05 & 0.02 & 0.05 \\
\hline Construction & 0.12 & 0.32 & 0.11 \\
\hline Distribution, Hotels \& Catering & 0.14 & 0.14 & 0.14 \\
\hline Transport \& Communication & 0.18 & 0.09 & 0.18 \\
\hline $\begin{array}{l}\text { Banking, Finance, Insurance, } \\
\text { Business Services \& Leasing }\end{array}$ & 0.21 & 0.20 & 0.21 \\
\hline
\end{tabular}




\begin{tabular}{|c|c|c|c|}
\hline Other Services & 0.13 & 0.15 & 0.13 \\
\hline Managers \& Administrators & 0.17 & 0.05 & 0.17 \\
\hline $\begin{array}{l}\text { Associate Professional \& } \\
\text { Technical Occupations }\end{array}$ & 0.14 & 0.04 & 0.14 \\
\hline Clerical \& Secretarial Occupations & 0.19 & 0.14 & 0.19 \\
\hline Craft \& Related Occupations & 0.10 & 0.03 & 0.10 \\
\hline $\begin{array}{c}\text { Personal \& Protective Service } \\
\text { Occupations }\end{array}$ & 0.10 & 0.27 & 0.09 \\
\hline Sales Occupations & 0.06 & 0.21 & 0.06 \\
\hline Plant \& Machine Operatives & 0.08 & 0.06 & 0.08 \\
\hline Other Occupations & 0.06 & 0.18 & 0.05 \\
\hline East Anglia & 0.04 & 0.05 & 0.04 \\
\hline East Midlands & 0.10 & 0.13 & 0.10 \\
\hline North West & 0.10 & 0.08 & 0.10 \\
\hline North East & 0.07 & 0.08 & 0.07 \\
\hline Scotland & 0.09 & 0.11 & 0.09 \\
\hline South West & 0.09 & 0.08 & 0.09 \\
\hline Wales & 0.06 & 0.10 & 0.05 \\
\hline West Midlands & 0.09 & 0.13 & 0.09 \\
\hline Yorkshire and Humberside & 0.09 & 0.10 & 0.09 \\
\hline Regional Bite of NMW & 0.50 & 0.52 & 0.50 \\
\hline Employment Rate & 0.71 & 0.71 & 0.71 \\
\hline 2000 & 0.27 & 0.28 & 0.27 \\
\hline 2001 & 0.23 & 0.24 & 0.23 \\
\hline 2002 & 0.18 & 0.19 & 0.18 \\
\hline 2003 & 0.17 & 0.14 & 0.17 \\
\hline Non-Employed at t-1 & 0.02 & 0.06 & 0.02 \\
\hline At or Below NMW at t-1 & 0.04 & 0.38 & 0.03 \\
\hline
\end{tabular}


Table 2: Unconditional and Conditional Probabilities of Being Employed at or Below the National Minimum Wage 1999-2004 (BHPS)

\begin{tabular}{|c|c|c|}
\hline & $\begin{array}{c}\text { Unconditional Probability } \\
\text { of NMW Employment }\end{array}$ & $\begin{array}{c}\text { Conditional Probability of } \\
\text { NMW }\end{array}$ \\
\hline Year & $\mathrm{P}\left(\mathrm{y}_{1 \mathrm{t}}=1\right)$ & $\mathrm{P}\left(\mathrm{y}_{1 \mathrm{t}}=1 \mid \mathrm{y}_{1 \mathrm{t}-1}=1\right)$ \\
\hline 1999 & 0.069 & 0.290 \\
\hline 2000 & 0.058 & 0.349 \\
\hline 2001 & 0.067 & 0.342 \\
\hline 2002 & 0.062 & 0.294 \\
\hline 2003 & 0.056 & 0.311 \\
\hline 2004 & 0.062 & \\
\hline
\end{tabular}

Entries restricted to the working age population but excluding students, individuals on government training programmes and the armed forces.

Table 3: Labour Market Status Transitions BHPS 1999-2004

\begin{tabular}{|c|c|c|c|}
\hline Origin & Not Employed & $\begin{array}{c}\text { Employed At or } \\
\text { Below NMW }\end{array}$ & $\begin{array}{c}\text { Employed Above } \\
\text { NMW }\end{array}$ \\
\hline Not Employed & 83.22 & 2.29 & 14.49 \\
\hline $\begin{array}{c}\text { Employed At or } \\
\text { Below NMW }\end{array}$ & 14.58 & 34.65 & 50.77 \\
\hline $\begin{array}{c}\text { Employed Above } \\
\text { NMW }\end{array}$ & 4.58 & 3.34 & 92.07 \\
\hline
\end{tabular}

Entries restricted to the working age population but excluding students, individuals on government training programmes and the armed forces. 
Table 4a: Employment At or Below the NMW (Dynamic Probit Estimates BHPS 2000-2004)

\begin{tabular}{|c|c|c|}
\hline & Pooled Probit & Random Effects Probit \\
\hline Female & $0.4784 * * * \quad(0.070)$ & $\begin{array}{c}0.5209 * * * \\
(0.086)\end{array}$ \\
\hline Age & $-0.0243 \quad(0.020)$ & $\begin{array}{c}0.2657 * * * \\
(0.103)\end{array}$ \\
\hline Age Squared & $0.0003 \quad(0.000)$ & $\begin{array}{c}-0.0022^{* *} \\
(0.001)\end{array}$ \\
\hline Degree/Equivalent & $-0.1561^{*} \quad(0.087)$ & $\begin{array}{l}-0.1636 \\
(0.106)\end{array}$ \\
\hline A-Level & $-0.0095 \quad(0.104)$ & $\begin{array}{l}0.0074 \\
(0.125)\end{array}$ \\
\hline O-Level & $-0.0763(0.092)$ & $\begin{array}{l}-0.0772 \\
(0.112)\end{array}$ \\
\hline Other Qualifications & $-0.1108 \quad(0.115)$ & $\begin{array}{l}-0.1102 \\
(0.139)\end{array}$ \\
\hline Poor Health & $0.2549 * * * \quad(0.098)$ & $\begin{array}{c}0.2923 * * * \\
(0.112)\end{array}$ \\
\hline Married & $-0.0012(0.078)$ & $\begin{array}{l}0.0139 \\
(0.094) \\
\end{array}$ \\
\hline Widowed/Separated/Divorced & $0.0228(0.100)$ & $\begin{array}{c}0.0301 \\
(0.1197)\end{array}$ \\
\hline Job Tenure & $-0.0013 * * *(0.000)$ & $\begin{array}{l}-0.0003 \\
(0.001)\end{array}$ \\
\hline Establishment 25-99 & $-0.1025 \quad(0.066)$ & $\begin{array}{c}-0.1094 \\
(0.077)\end{array}$ \\
\hline Establishment 100-499 & $-0.1452 *(0.075)$ & $\begin{array}{c}-0.1503^{*} \\
(0.087)\end{array}$ \\
\hline Establishment 500+ & $-0.4457 * * * \quad(0.111)$ & $\begin{array}{c}-0.4909 * * * \\
(0.130)\end{array}$ \\
\hline Managerial Responsibility & $-0.2090 *(0.111)$ & $\begin{array}{c}-0.2269 * \\
(0.127)\end{array}$ \\
\hline Supervisory Responsibility & $-0.1821 * * \quad(0.079)$ & $\begin{array}{c}-0.2074^{* *} \\
(0.091)\end{array}$ \\
\hline Promotion Possibilities & $-0.1255^{* *} \quad(0.057)$ & $\begin{array}{c}-0.1173^{*} \\
(0.066)\end{array}$ \\
\hline Full Time & $-0.0779 \quad(0.064)$ & $\begin{array}{l}-0.0710 \\
(0.075)\end{array}$ \\
\hline $\begin{array}{c}\text { Union/Staff Association at } \\
\text { Workplace }\end{array}$ & $-0.2813^{* * *}(0.061)$ & $-0.2954 * * * \quad(0.073)$ \\
\hline $\begin{array}{l}\text { Extraction; Manufacture of } \\
\text { Metals, Mineral Products \& } \\
\text { Chemicals }\end{array}$ & $-0.1746(0.200)$ & $\begin{array}{l}-0.1586 \\
(0.232)\end{array}$ \\
\hline $\begin{array}{c}\text { Metal Goods, Engineering \& } \\
\text { Vehicles Industries }\end{array}$ & $-0.2614(0.217)$ & $\begin{array}{l}-0.3066 \\
(0.251)\end{array}$ \\
\hline Other Manufacturing & $-0.2496(0.223)$ & $\begin{array}{l}-0.2593 \\
(0.254)\end{array}$ \\
\hline
\end{tabular}




\begin{tabular}{|c|c|c|}
\hline Construction & $0.3182 *(0.183)$ & $\begin{array}{l}0.3553^{*} \\
(0.214)\end{array}$ \\
\hline Distribution, Hotels \& Catering & $-0.0801(0.191)$ & $\begin{array}{l}-0.0871 \\
(0.221)\end{array}$ \\
\hline Transport \& Communication & $-0.1853 \quad(0.190)$ & $\begin{array}{l}-0.1738 \\
(0.220)\end{array}$ \\
\hline $\begin{array}{l}\text { Banking, Finance, Insurance, } \\
\text { Business Services \& Leasing }\end{array}$ & $-0.0616 \quad(0.189)$ & $\begin{array}{l}-0.0753 \\
(0.220)\end{array}$ \\
\hline Other Services & $-0.0826(0.198)$ & $\begin{array}{l}-0.0948 \\
(0.230)\end{array}$ \\
\hline Managers \& Administrators & $0.3291(0.203)$ & $\begin{array}{l}0.3302 \\
(0.229)\end{array}$ \\
\hline $\begin{array}{c}\text { Associate Professional \& } \\
\text { Technical Occupations }\end{array}$ & $0.3416^{*}(0.196)$ & $\begin{array}{l}0.3565 \\
(0.223)\end{array}$ \\
\hline $\begin{array}{c}\text { Clerical \& Secretarial } \\
\text { Occupations }\end{array}$ & $0.4189 * * \quad(0.188)$ & $\begin{array}{c}0.4198^{* *} \\
(0.214)\end{array}$ \\
\hline Craft \& Related Occupations & $0.4057 * \quad(0.217)$ & $\begin{array}{l}0.3697 \\
(0.249)\end{array}$ \\
\hline $\begin{array}{c}\text { Personal \& Protective Service } \\
\text { Occupations }\end{array}$ & $0.9763 * * * \quad(0.182)$ & $\begin{array}{c}1.0327 * * * \\
(0.210)\end{array}$ \\
\hline Sales Occupations & $0.8580 * * * \quad(0.195)$ & $\begin{array}{c}0.8879 * * * \\
(0.224)\end{array}$ \\
\hline Plant \& Machine Operatives & $0.7654 * * * \quad(0.207)$ & $\begin{array}{c}0.7709 * * * \\
(0.237)\end{array}$ \\
\hline Other Occupations & $1.0581 * * * \quad(0.192)$ & $\begin{array}{c}1.0928 * * * \\
(0.222)\end{array}$ \\
\hline East Anglia & $0.0081 \quad(0.174)$ & $\begin{array}{l}0.0112 \\
(0.416)\end{array}$ \\
\hline East Midlands & $0.1568(0.186)$ & $\begin{array}{l}0.1649 \\
(0.507)\end{array}$ \\
\hline North West & $-0.0276 \quad(0.174)$ & $\begin{array}{l}0.0414 \\
(0.450)\end{array}$ \\
\hline North East & $0.0856(0.214)$ & $\begin{array}{l}0.1102 \\
(0.622)\end{array}$ \\
\hline Scotland & $0.1010(0.166)$ & $\begin{array}{l}0.0856 \\
(0.443)\end{array}$ \\
\hline South West & $-0.0298 \quad(0.149)$ & $\begin{array}{l}-0.0832 \\
(0.315)\end{array}$ \\
\hline Wales & $0.2824(0.210)$ & $\begin{array}{l}0.3903 \\
(0.579)\end{array}$ \\
\hline West Midlands & $0.2562 \quad(0.161)$ & $\begin{array}{c}0.2747 \\
(0.407)\end{array}$ \\
\hline Yorkshire and Humberside & $0.0531 \quad(0.204)$ & $\begin{array}{l}0.0509 \\
(0.548)\end{array}$ \\
\hline Regional Bite of NMW & $1.4928(1.302)$ & $\begin{array}{l}0.4883 \\
(1.567)\end{array}$ \\
\hline Employment Rate & $-0.1853(0.733)$ & $\begin{array}{l}-1.6949 \\
(1.085)\end{array}$ \\
\hline 2000 & $0.0323 \quad(0.104)$ & 0.2717 \\
\hline
\end{tabular}




\begin{tabular}{|c|c|c|}
\hline & & $(0.240)$ \\
\hline 2001 & $-0.0363(0.092)$ & $\begin{array}{l}0.1552 \\
(0.189)\end{array}$ \\
\hline 2002 & $\begin{array}{ll}-0.0367 & (0.094)\end{array}$ & $\begin{array}{l}0.1150 \\
(0.153)\end{array}$ \\
\hline 2003 & $-0.2181 * * \quad(0.094)$ & $\begin{array}{l}-0.1344 \\
(0.118)\end{array}$ \\
\hline Non-Employed at t-1 & $0.4880 * * *(0.124)$ & $\begin{array}{l}0.4167^{* * *} \\
(0.142)\end{array}$ \\
\hline At or Below NMW at t-1 & $1.0953 * * * \quad(0.071)$ & $\begin{array}{c}0.5861 * * * \\
(0.110)\end{array}$ \\
\hline Constant & $-2.4548 * * * \quad(0.749)$ & $-3.7909 * * * \quad(1.157)$ \\
\hline$\rho$ & & $\begin{array}{l}0.2004 \\
{[0.000]}\end{array}$ \\
\hline Log Likelihood & -1400.8227 & -1365.9926 \\
\hline$\chi_{1}^{2}$ & $\begin{array}{l}1248.90 \\
{[0.000]}\end{array}$ & $\begin{array}{l}646.96 \\
{[0.000]}\end{array}$ \\
\hline$\chi_{2}^{2}\left[\left(\alpha_{y_{1 t-1}}-\alpha_{y_{2 t-1}}\right)=0\right]$ & $\begin{array}{c}20.00 \\
{[0.000]}\end{array}$ & $\begin{array}{c}1.03 \\
{[0.3107]}\end{array}$ \\
\hline Sample Size & 11349 & 11349 \\
\hline$\hat{\mathrm{p}}_{0}$ & 0.0307 & 0.0277 \\
\hline$\hat{\mathrm{p}}_{1}$ & 0.0711 & 0.0535 \\
\hline$\hat{\mathrm{p}}_{2}$ & 0.1670 & 0.0686 \\
\hline$\hat{\mathrm{p}}_{1}-\hat{\mathrm{p}}_{0}$ & 0.0404 & 0.0259 \\
\hline$\hat{\mathrm{p}}_{2}-\hat{\mathrm{p}}_{0}$ & 0.1363 & 0.0409 \\
\hline$\hat{\mathrm{p}}_{1} / \hat{\mathrm{p}}_{0}$ & 2.3169 & 1.9346 \\
\hline$\hat{\mathrm{p}}_{2} / \hat{\mathrm{p}}_{0}$ & 5.4460 & 2.4776 \\
\hline$\hat{\mathrm{p}}_{2} / \hat{\mathrm{p}}_{1}$ & 2.3505 & 1.2807 \\
\hline
\end{tabular}

Notes:

1. * signifies significance at the $10 \%$ level; ** signifies significance at the $5 \%$ level; and $* * *$ signifies significance at the $1 \%$ level.

2. Standard errors in rounded parentheses and p-values in square brackets.

3. $\chi_{1}^{2}$ is a test of whether all the slope coefficients are equal to zero; and $\chi_{2}^{2}$ is a test of whether the coefficients on the lagged labour market status variables are equal to one another.

4. Omitted categorical variables are no qualifications; single; establishment size less than 25; agriculture, forestry and fishing; professional; London and the South-East; and 2004.

5. $\hat{\mathrm{p}}_{0}, \hat{\mathrm{p}}_{1}$, and $\hat{\mathrm{p}}_{2}$ are defined in the text. 
Table 4b: Employment At or Below the NMW (Dynamic Probit Estimates BHPS 2000-2004)

\begin{tabular}{|c|c|c|}
\hline & Pooled Probit & Random Effects Probit \\
\hline Female & $0.4792 * * * \quad(0.070)$ & $\begin{array}{c}0.5179 * * * \\
(0.086)\end{array}$ \\
\hline Age & $-0.0240(0.020)$ & $\begin{array}{l}0.2520^{* *} \\
(0.102)\end{array}$ \\
\hline Age Squared & $0.0003 \quad(0.000)$ & $\begin{array}{c}-0.0022^{* *} \\
(0.001)\end{array}$ \\
\hline Degree/Equivalent & $-0.1552 *(0.087)$ & $\begin{array}{l}-0.1598 \\
(0.105)\end{array}$ \\
\hline A-Level & $-0.0077 \quad(0.1035)$ & $\begin{array}{l}0.0144 \\
(0.125)\end{array}$ \\
\hline O-Level & $-0.0778 \quad(0.092)$ & $\begin{array}{l}-0.0771 \\
(0.111)\end{array}$ \\
\hline Other Qualifications & $-0.1109 \quad(0.115)$ & $\begin{array}{l}-0.1057 \\
(0.139)\end{array}$ \\
\hline Poor Health & $0.2576 * * * \quad(0.098)$ & $\begin{array}{l}0.2915^{* * *} \\
(0.111)\end{array}$ \\
\hline Married & $0.0001(0.078)$ & $\begin{array}{l}0.0168 \\
(0.093) \\
\end{array}$ \\
\hline Widowed/Separated/Divorced & $0.0250 \quad(0.100)$ & $\begin{array}{l}0.0380 \\
(0.119)\end{array}$ \\
\hline Job Tenure & $-0.0013^{* * *}(0.0004)$ & $\begin{array}{l}-0.0003 \\
(0.001)\end{array}$ \\
\hline Establishment 25-99 & $-0.1017(0.066)$ & $\begin{array}{c}-0.1109 \\
(0.077)\end{array}$ \\
\hline Establishment 100-499 & $-0.1433^{*} \quad(0.075)$ & $\begin{array}{l}-0.1512^{*} \\
(0.086)\end{array}$ \\
\hline Establishment 500+ & $-0.4474 * * * \quad(0.112)$ & $\begin{array}{c}-0.4951^{* * *} \\
(0.130)\end{array}$ \\
\hline Managerial Responsibility & $-0.2083 *(0.110)$ & $\begin{array}{c}-0.2242^{*} \\
(0.127)\end{array}$ \\
\hline Supervisory Responsibility & $-0.1824 * *(0.079)$ & $\begin{array}{c}-0.2082^{* *} \\
(0.091)\end{array}$ \\
\hline Promotion Possibilities & $-0.1261 * *(0.057)$ & $\begin{array}{c}-0.1192^{*} \\
(0.066)\end{array}$ \\
\hline Full Time & $-0.0782(0.064)$ & $\begin{array}{l}-0.0715 \\
(0.075)\end{array}$ \\
\hline $\begin{array}{c}\text { Union/Staff Association at } \\
\text { Workplace }\end{array}$ & $-0.2842 * * * \quad(0.061)$ & $\begin{array}{c}-0.2977 * * * \\
(0.073)\end{array}$ \\
\hline $\begin{array}{l}\text { Extraction; Manufacture of } \\
\text { Metals, Mineral Products \& } \\
\text { Chemicals }\end{array}$ & $-0.1739 \quad(0.200)$ & $\begin{array}{l}-0.1557 \\
(0.231)\end{array}$ \\
\hline $\begin{array}{c}\text { Metal Goods, Engineering \& } \\
\text { Vehicles Industries }\end{array}$ & $-0.2629(0.217)$ & $\begin{array}{l}-0.3054 \\
(0.250)\end{array}$ \\
\hline Other Manufacturing & $-0.2531 \quad(0.224)$ & $\begin{array}{l}-0.2584 \\
(0.253)\end{array}$ \\
\hline
\end{tabular}




\begin{tabular}{|c|c|c|}
\hline Construction & $0.3198 *(0.183)$ & $\begin{array}{l}0.3555^{*} \\
(0.213)\end{array}$ \\
\hline Distribution, Hotels \& Catering & $-0.0785(0.191)$ & $\begin{array}{l}-0.0866 \\
(0.220) \\
\end{array}$ \\
\hline Transport \& Communication & $-0.1823 \quad(0.190)$ & $\begin{array}{l}-0.1751 \\
(0.219)\end{array}$ \\
\hline $\begin{array}{l}\text { Banking, Finance, Insurance, } \\
\text { Business Services \& Leasing }\end{array}$ & $-0.0586 \quad(0.189)$ & $\begin{array}{l}-0.0716 \\
(0.219)\end{array}$ \\
\hline Other Services & $-0.0810 \quad(0.198)$ & $\begin{array}{l}-0.0940 \\
(0.229)\end{array}$ \\
\hline Managers \& Administrators & $0.3287 \quad(0.203)$ & $\begin{array}{l}0.3291 \\
(0.227)\end{array}$ \\
\hline $\begin{array}{c}\text { Associate Professional \& } \\
\text { Technical Occupations }\end{array}$ & $0.3422 *(0.196)$ & $\begin{array}{l}0.3529 \\
(0.221)\end{array}$ \\
\hline $\begin{array}{c}\text { Clerical \& Secretarial } \\
\text { Occupations }\end{array}$ & $0.4199 * * \quad(0.187)$ & $\begin{array}{l}0.4174 \\
(0.212)\end{array}$ \\
\hline Craft \& Related Occupations & $0.4086^{*}(0.217)$ & $\begin{array}{l}0.3726 \\
(0.247)\end{array}$ \\
\hline $\begin{array}{c}\text { Personal \& Protective Service } \\
\text { Occupations }\end{array}$ & $0.9752 * * * \quad(0.182)$ & $\begin{array}{l}1.0261^{* * *} \\
(0.208)\end{array}$ \\
\hline Sales Occupations & $0.8589 * * * \quad(0.195)$ & $\begin{array}{c}0.8840 * * * \\
(0.222)\end{array}$ \\
\hline Plant \& Machine Operatives & $0.7690 * * * \quad(0.207)$ & $\begin{array}{l}0.7719 * * * \\
(0.235)\end{array}$ \\
\hline Other Occupations & $1.0603 * * * \quad(0.191)$ & $\begin{array}{c}1.0910 * * * \\
(0.220)\end{array}$ \\
\hline East Anglia & $0.1187(0.136)$ & $\begin{array}{l}0.0970 \\
(0.164) \\
\end{array}$ \\
\hline East Midlands & $0.3419 * * * \quad(0.094)$ & $\begin{array}{c}0.3705^{* * *} \\
(0.113)\end{array}$ \\
\hline North West & $0.1168 \quad(0.105)$ & $\begin{array}{l}0.1391 \\
(0.124)\end{array}$ \\
\hline North East & $0.2613 * * \quad(0.113)$ & $\begin{array}{l}0.2514^{*} \\
(0.139)\end{array}$ \\
\hline Scotland & $0.2438 * * \quad(0.100)$ & $\begin{array}{l}0.2188^{*} \\
(0.122)\end{array}$ \\
\hline South West & $0.0946(0.106)$ & $\begin{array}{l}0.0858 \\
(0.128)\end{array}$ \\
\hline Wales & $0.4619 * * * \quad(0.113)$ & $\begin{array}{c}0.5005^{* * *} \\
(0.137)\end{array}$ \\
\hline West Midlands & $0.3937 * * * \quad(0.098)$ & $\begin{array}{c}0.4180 * * * \\
(0.118)\end{array}$ \\
\hline Yorkshire and Humberside & $0.2500 * * \quad(0.102)$ & $\begin{array}{l}0.2482 * * \\
(0.122)\end{array}$ \\
\hline 2000 & $-0.0857 \quad(0.093)$ & $\begin{array}{l}0.20267 \\
(0.222)\end{array}$ \\
\hline 2001 & $-0.0804 \quad(0.084)$ & $\begin{array}{l}0.1128 \\
(0.175)\end{array}$ \\
\hline 2002 & $-0.0727(0.088)$ & 0.0788 \\
\hline
\end{tabular}




\begin{tabular}{|c|c|c|}
\hline & & $(0.144)$ \\
\hline 2003 & $-0.2238 * * \quad(0.094)$ & $\begin{array}{l}-0.1509 \\
(0.116)\end{array}$ \\
\hline Non-Employed at t-1 & $0.4850^{* * *}(0.124)$ & $\begin{array}{c}0.4112^{* * *} \\
(0.141)\end{array}$ \\
\hline At or Below NMW at t-1 & $1.0950^{* * *}(0.071)$ & $\begin{array}{c}0.5896^{* * *} \\
(0.110)\end{array}$ \\
\hline Constant & $-1.9235 * * * \quad(0.483)$ & $\begin{array}{l}-2.4187^{* * *} \\
(0.606)\end{array}$ \\
\hline$\rho$ & & $\begin{array}{l}0.1968 \\
{[0.000]}\end{array}$ \\
\hline Log Likelihood & -1401.5387 & -1368.325 \\
\hline$\chi_{1}^{2}$ & $\begin{array}{l}1247.47 \\
{[0.000]}\end{array}$ & $\begin{array}{l}652.36 \\
{[0.000]}\end{array}$ \\
\hline$\chi_{2}^{2}\left[\left(\alpha_{y_{1 t-1}}-\alpha_{y_{2 t-1}}\right)=0\right]$ & $\begin{array}{c}20.21 \\
{[0.000]}\end{array}$ & $\begin{array}{c}1.15 \\
{[0.2835]}\end{array}$ \\
\hline Sample Size & 11349 & 11349 \\
\hline$\hat{\mathrm{p}}_{0}$ & 0.0307 & 0.0277 \\
\hline$\hat{\mathrm{p}}_{1}$ & 0.0707 & 0.0533 \\
\hline$\hat{\mathrm{p}}_{2}$ & 0.1670 & 0.0692 \\
\hline$\hat{\mathrm{p}}_{1}-\hat{\mathrm{p}}_{0}$ & 0.0401 & 0.0256 \\
\hline$\hat{\mathrm{p}}_{2}-\hat{\mathrm{p}}_{0}$ & 0.1363 & 0.0414 \\
\hline$\hat{\mathrm{p}}_{1} / \hat{\mathrm{p}}_{0}$ & 2.3069 & 1.9221 \\
\hline$\hat{\mathrm{p}}_{2} / \hat{\mathrm{p}}_{0}$ & 5.4478 & 2.4966 \\
\hline$\hat{\mathrm{p}}_{2} / \hat{\mathrm{p}}_{1}$ & 2.3615 & 1.2989 \\
\hline
\end{tabular}

Notes:

1. * signifies significance at the $10 \%$ level; ** signifies significance at the $5 \%$ level; and *** signifies significance at the $1 \%$ level.

2. Standard errors in rounded parentheses and p-values in square brackets.

3. $\chi_{1}^{2}$ is a test of whether all the slope coefficients are equal to zero; and $\chi_{2}^{2}$ is a test of whether the coefficients on the lagged labour market status variables are equal to one another.

4. Omitted categorical variables are no qualifications; single; establishment size less than 25; agriculture, forestry and fishing; professional; London and the South-East; and 2004.

5. $\hat{\mathrm{p}}_{0}, \hat{\mathrm{p}}_{1}$, and $\hat{\mathrm{p}}_{2}$ are defined in the text. 


\section{References}

Arulampalam, W., Booth, A.L. and Taylor, M.P., "Unemployment Persistence", Oxford Economic Papers, vol. 52, 2000, pp.24-50

Asplund, R., Sloane, P.J. and Theodossiou, I., editors,

Low Pay and Earnings Mobility in Europe, Aldershot, Edward Elgar, 1998

Bradley, S., Crouchley, R. and Oskrochi, R.,

Social Exclusion and Labour Market Transitions: A Multi-state, Multi-spell Analysis using the BHPS, Labour Economics, Vol. 10, No. 6, December, 2003, pp 659-679.

Burchardt, T. and McKnight, A.,

'Disability and the National Minimum Wage: A Special Case', ESRC Centre for Analysis of Social Exclusion, London School of Economics, April, 2003.

Cappellari, L. and Jenkins, S.P.,

Modelling Low Pay Transition Probabilities, Accounting for Panel Attrition, NonResponse, and Initial Conditions, ISER Working Paper No. 2004-08, University of Essex, 2004.

Chamberlain, G.,

Panel Data in Griliches, Z. and Intrilligator, M., editors, Handbook of Econometrics, North Holland, Amsterdam, 1984.

Dex, S., Sutherland, H. and Joshi, H.,

'Effects of Minimum Wages on the Gender Pay Gap,

National Institute Economic Review, No. 173, July, 2000, pp 80-88

Dickens, R. and Manning, A.,

'Has the National Minimum Wage Reduced UK Wage Inequality?' Journal of the Royal Statistical Society, Series A, Vol. 167, part 4, 2002, pp 613-626

Evan, W.E. and Macpherson, D.A.

'The Wage and Employment Dynamics of Minimum Wage Workers',

Southern Economic Journal, Vol. 69 (3), 2003, pp. 676-690

Heckman, J.

'The Incidental Parameters Problem and the Problem of Initial Conditions in Estimating a Discrete Time-Discrete Data Stochastic Process', C. Manski and D. MsFadden (eds), Structural Analysis of Discrete Data with Econometric Applications, MIT Press ,Cambridge MA, 1981, pp178-195.

Heckman, J.

'Heterogeneity and State Dependence', in S. Rosen (ed.), Studies in Labor Markets, Chicago, University of Chicago Press, 1981

Jones M. K., Jones R.J., Murphy P.D. and Sloane P.J. An Analysis of Flows into and Out of the National Minimum Wage, A Report for the Low Pay Commission, September, 2004, pp. 69 
Kaitz, H.,

'Experience of the Past: The National Minimum, Youth Unemployment and Minimum Wages', US Bureau of Labor Statistics Bulletin, 1657, 1970, pp 30-54

Lee, L.,

'Some Approaches to the Correction of Selectivity Bias', Review of Economics and Statistics, Vol. 49, 1982.

Lemos, S.,

'Are Wage and Employment Effects Robust to Alternative Minimum Wage Variables?

IZA Discussion Paper, No. 1070, March, 2004.

Mundlak, Y.,

On the Pooling of Times Series and Cross-section Data, Econometrica, Vol. 46, 1978, pp 69-81.

Orme, C.,

'The Initial Conditions Problem and Two-Step Estimation in Discrete Panel Data', mimeo, Department of Economics, University of Manchester, 1997.

Robinson, $\mathrm{H}$.

'Wrong Side of the Track', The Impact of the Minimum Wage on Gender Pay Gaps in Britain', Oxford Bulletin of Economics and Statistics, Vol. 64, No. 5, 2002, pp 417-448.

Schiller, B.R.,

'Moving Up; The Training and Wage Gains of Minimum Wage Entrants',

Social Science Quarterly, Vol. 75, 1994, pp. 622-36

Skinner, S., Stuttard, N., Beissel-Durrant, G., and Jenkins, J., 'The Measurement of Low Pay in the UK Labour Force Survey'.

Oxford Bulletin of Economics and Statistics, Vol. 64, supplement, December, 2000, pp. 653-676

Sloane, P.J. and Theodossiou, I.,

'Earnings Mobility of the Low Paid', in Gregory, M., Salverda, W. and Bazen, S., editors, Labour Market Inequalities, Oxford, Oxford University Press, 2000

Smith, R.E. and Vavrichek, B.,

'The Wage Mobility of Minimum Wage Workers',

Industrial and Labor Relations Review, Vol. 46, 1992, pp. 82-8

Stewart, M.

Low Pay, No Pay Dynamics in Persistent Poverty and Lifetime Inequality, H.M. Treasury Occasional Paper No. 10, 1999.

Stewart, M.

'Estimating the Impact of the Minimum Wage Using Geographical Wage Variation', Oxford Bulletin of Economics and Statistics, Vol. 64, supplement, December, 2002 pp. 583-605 
Stewart, M.

The Inter-related Dynamics of Unemployment and Low-Wage Employment, Warwick Economic Research Paper No. 741, Department of Economics, University of Warwick, December, 2005.

Stewart, M. and Swaffield, J.K.

Using the BHPS Wave 9 Additional Questions to Evaluate the Impact of the National Minimum Wage,

Oxford Bulletin of Economics and Statistics, Vol. 64, supplement, December, 2002, pp. 633-52

Stewart, M. and Swaffield, J.

'Low Pay Dynamics and Transition Probabilities', Economica, Vol. 66, 1999, pp 23-42.

Taylor, M..F. (ed) with Brice, J., Buck, No. and Prentice-Lane, E. (2001), British Household Panel Survey User Manual (A: Introduction, Technical Report and Appendices). Colchester: University of Essex.

Wooldridge, J.M.,

Simple Solutions to the Initial Conditions Problem in Dynamic, Non-linear Panel Data Models with Unobserved Heterogeneity, Journal of Applied Econometrics, Vol. 20, 2005, pp 39-54. 